\title{
Individualized Education Plans in Canada: A Comparative Analysis
}

\author{
Philippe Tremblay, Stéphanie Belley \\ Université Laval, Québec
}

\begin{abstract}
A comparative analysis of individualized education plans (IEP) for special needs students was conducted in Canada's ten provinces and three territories, with a focus on the content and functions of these support methods. Despite the legal obligation of individualized education plans (IEP), research on their elaboration and use remains rare. In this context, the present study sheds light on the associated mandatory elements and functions of these interventions (communication, identification, planning, collaboration, adaptation, review, and transition). Various types of public education documentation were analyzed based on the classification systems of Higgins and Berresi [1]; Poirier, Goguen, and Leslie [2]; and AuCoin, Goguen, and Vienneau [3].
\end{abstract}

\section{Introduction}

In Canada as well as in the United States, the individualized education plan (IEP) constitutes a legal right [4]. The concept of the individualized education plan is not new: this term first appeared in the United States in 1975 with the adoption of the Individuals with Disabilities Education Act (IDEA) which guaranteed access to free public education to meet the needs of every student between the ages of 3 and 21 [5] [6] [7]. One of the fundamental principles of the IDEA was the development and implemention of an intervention plan for special needs students. The IEP refers to both the educational program to be provided to a child with a disability and the written document describing this instructional program.

In special needs education, no document is more important than the intervention plan, as it enables to ensure the application of a program that is both specifically tailored to this particular clientele [8] and fully compliant under the law [4] [9]. "According to American law, the term individualized education program or IEP means a written statement for each child with a disability that is developed, reviewed, and revised in a meeting (...)" (IDEA, 2004, part 300). In addition, this document must house specific data, including the current performance level of the child (academic, functional, and social), the annual goals and measurable shortterm objectives, any specific education services (changes or adaptations to the study program) provided for the child, the date and expected duration of said services, as well as achievement criteria and the assessment dates and details [5].

In Canada, how it is implemented differs from one province and territory to another. Indeed, the federal government of Canada detains no constitutional authority here, as education is the sole responsibility of the provincial governments. Thus, in this federal system of distributed power, the Canadian Constitution Act of 1867 [10] states that "each province may exclusively make laws in relation to Education, subject and according to certain provisions" (art. 93). Canada therefore has no federal Minister of Education, nor any national integrated education system.

Therefore, in each of the country's 13 school jurisdictions (ten provinces and three territories), the Minister of Education determines the organization, performance, and assessment of elementary and secondary education. On the local level, however, elected school jurisdictions (or Boards) manage and supervise a school district and its employees. School districts may be organized on the basis of language or religious denomination. Provincial or territorial education policies may therefore differ, not only between provinces and territories but also between school jurisdictions.

The most recent dictionary in the field of education [11] defines the individualized education plans (IEP) as resulting from the systematic planning of instructional measures required to meet the needs of students with intellectual or physical difficulties. In the United States, Barton [12] refers to this plan as a legal document describing the necessary services and support actions for special needs students (meeting appropriate eligibility criteria) between the ages of 3 and 22. Legendre [11] adds that contrary to the service plan, the individualized education plan (IEP) is limited to one field of activity, such as education, rehabilitation, etc. 


\section{Conceptual Framework}

The concept of the individualized education plan (IEP) first emerged in 1975, when the United States introduced legislation named Education for All Handicapped Children Act (EAHCA), followed by the adoption of the Individuals with Disabilities Education Act (IDEA) (Drasgow, Mitchell \& Robinson [6] ; Rodger [7]). Indeed, among the fundamental principles of the IDEA was the development and implementation of an intervention plan for students with learning or behavior difficulties (Smith [9]). The U.S. government defined the individualized education plan or IEP as a legal document to specifically meet the needs of each learning-challenged student. The IEP is prepared by a team consisting of an education specialist, the teacher, the parents or tutor and, if need be, the student (IDEA). IDEA also stated that this document must detail the student's current progress, the relevant short-term and annual goals, the education services (including modifications to the program) provided and relevant data pertaining to said services, as well as achievement criteria and the dates and details of all assessments (Mitchell, Morton, \& Hornby [5]). Finally, this written document determines the IEP of the special needs student and describes the program itself.

In special education, no document is more important than the IEP which ensures the development and implementation of a program that is both specifically tailored for this specific student population (Christle \& Yell [8]) and legally compliant (Rotter, 2014 [4]; Smith [9]). Québec's Public Education Act made it mandatory that school districts establish an intervention plan for special needs students. Inspired by the American standard for IEPs, many Canadian provinces developed guidelines for this practice. However, while many provinces have their own IP models, each district or school council may opt for a different IP canvas. For example, in Québec (1988), the Law on Public Education article 235 states that the IEP must comply with the established policies of the school district regarding handicapped students and those with learning or behavior disorders.

Seven components of the individualized education plans (IEP) were identified for analysis: communication, identification, planning, collaboration, adaptation, review, and transition. Two prerequisite features guided the analysis, namely that the functions support the central components of the individualized education plans, and that they extend over time to enable the IEP to sollicit several functions at different times during the course of its elaboration process (see Table 1).

As described by the Ministry of Education of the province of Québec (MEQ) [13] and by Bateman and Bateman [14], the IEP consists of a written form of communication when it facilitates discussion centered on the student's specific needs and when it presents a detailed plan to meet these needs.

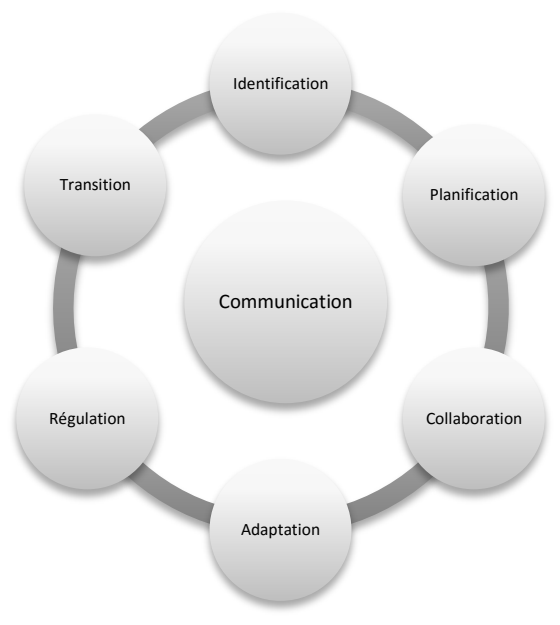

Figure 1. Keywords and the framework (Tremblay \& Belley, 2017)

In terms of identification, a screening process is introduced which in many provinces and territories has replaced the more categorical diagnostic practices. Moreover, in the event of required structural preparation for the formal design of a specific intervention strategy, planning comes into play. As proposed by the MEQ [13], this involves the distribution of responsibilities between the parties involved to contribute more efficiently to the development of the IEP and ultimately, its success. This function also takes into account the parents' rights and their role in the IP's development process. Once this is achieved, collaboration comes to the forefront, as the entire team must focus their pedagogical actions in one direction to ensure the attainment of the targeted goals. Adaptation of the IEP follows suite to encompass the various accommodations (adaptations and modifications) for the student that have been authorized and documented in the intervention process. Thereafter, the review process takes into account the propositions of Bateman and Bateman [14] of the South Dakota Department of Education [15] and the MEQ [13] to monitor the student's progress and make the appropriate adjustments if deemed necessary. Following these changes throughout the school year is thus encouraged to better guide the progress and outcomes of these students [13]. Finally, the function of transition relates to the continuity of pedagogical strategies to support special needs students as they head into the next phase of their lives [13]. The transitional process may thus be useful during the passage from elementary to secondary school or when a student is transferred from one school to another [16]. 


\section{Research objectives}

The goal of this research project was the comparative study of IEP for special needs students across Canada (ten provinces and three territories) with emphasis on the content and functions. Although IEPs are considered legal actions in Canadian schools, few studies have addressed these particular aspects in the area of special education. This analysis hopefully sheds light on their different mandatory elements and deployment.

\section{Methodology}

An analysis of individualized education plans for special needs students was performed by examining three types of education policy documentation [1] [2] [3]. Specifically, Type I refers to constitutional considerations, charters of rights, and other such legislation (Ex.: Education Act).

\section{Table 1. Typology of official texts}

\begin{tabular}{|c|}
\hline Type 1 \\
\hline Constitutions \\
\hline $\begin{array}{l}\text { Constitutions are fundamental laws that define individual } \\
\text { rights and freedoms (Ex. charters) as well as the organization } \\
\text { and distribution of political power (legislative, executive, } \\
\text { judicial). }\end{array}$ \\
\hline Legislation \\
\hline $\begin{array}{l}\text { Laws are first presented in the form of a legislative proposal } \\
\text { which is examined on several levels by the Members of } \\
\text { Parliament. The proposed bill becomes an official law only } \\
\text { when it is adopted by the MPs and sanctioned by the } \\
\text { Governor or Lieutenant Governor. Of note is that when } \\
\text { proposed legislation is accepted as a provincial law, it can } \\
\text { only be rectified by another formal legislative process. }\end{array}$ \\
\hline International Agreements \\
\hline $\begin{array}{l}\text { International agreements are ratified by Canada and/or by the } \\
\text { provinces and are voted upon by the Members of Parliament. }\end{array}$ \\
\hline Type 2 \\
\hline Politicies \\
\hline $\begin{array}{l}\text { A policy designates an action plan that is developed by a } \\
\text { government Ministry. Policies must be compatible with } \\
\text { existing laws and regulations and require the final approval of } \\
\text { the Minister involved. Policies provide direction for school } \\
\text { jurisdictions and their respective boards of directors who are } \\
\text { responsible for ensuring their compliance. }\end{array}$ \\
\hline Ministerial Directives \\
\hline $\begin{array}{l}\text { Ministerial letters and directives may be drawn up when a } \\
\text { Ministry strives for a certain political uniformity. Often quasi- } \\
\text { legislative in nature, these directives are normally used to } \\
\text { clarify legislation and render them applicable. }\end{array}$ \\
\hline $\begin{array}{ll}\text { Type } 3 \\
\end{array}$ \\
\hline Guides \\
\hline $\begin{array}{l}\text { Guides are produced to help education professionals to better } \\
\text { develop and perform their tasks and responsibilities, in } \\
\text { compliance with the law and the rules pertaining to a given } \\
\text { domain. }\end{array}$ \\
\hline Support Documentation \\
\hline $\begin{array}{l}\text { Support documents are developed by the Minister of } \\
\text { Education to provide guidance to school districts with regard } \\
\text { to professional practices. }\end{array}$ \\
\hline
\end{tabular}

Type II refers to administrative documents pertaining to the implementation of instructional measures for these students, as well as the human, organizational, financial, and material resources involved to provide the necessary services. Type III documents, reserved for educators and other education specialists, include the professional techniques and interventions to use with special needs students, as well as practical procedures and guidelines for both the teachers and parents of these students.

For the purposes of this analysis, all of the government laws and policies specific to each Canadian province and territory were gathered and documented by directly accessing the various government websites. This effort resulted in a list of 25 texts.

Table 2. Sources of official documents

\begin{tabular}{|c|c|c|}
\hline Provinces/Territoires & Date & $\begin{array}{c}\text { Documents types } 1 \text { et } 2 \\
\text { Lois et politiques } \\
\text { gouvernementales }\end{array}$ \\
\hline \multirow[t]{2}{*}{ Alberta } & 2004 & $\begin{array}{l}\text { Standards for Special } \\
\text { Education }\end{array}$ \\
\hline & $\begin{array}{l}2000- \\
2013\end{array}$ & School act \\
\hline \multirow[t]{2}{*}{ British Columbia } & 2013 & $\begin{array}{l}\text { Special Education } \\
\text { Services: A Manual of } \\
\text { Policies, Procedures and } \\
\text { Guidelines. }\end{array}$ \\
\hline & $\begin{array}{l}1996- \\
2016\end{array}$ & School act \\
\hline \multirow[t]{2}{*}{$\begin{array}{c}\text { Prince Edward } \\
\text { Island }\end{array}$} & 2001 & $\begin{array}{l}\text { Minister's Directive No. } \\
\text { MD 2001-08. }\end{array}$ \\
\hline & $\begin{array}{l}1993- \\
2013\end{array}$ & School Act \\
\hline \multirow[t]{2}{*}{ New Brunswick } & 2013 & $\begin{array}{l}\text { Policy } 322 \text { Inclusive } \\
\text { Education }\end{array}$ \\
\hline & $\begin{array}{l}1997- \\
2016\end{array}$ & Loi sur l'éducation \\
\hline \multirow[t]{2}{*}{ Manitoba } & $\begin{array}{l}2006- \\
2016\end{array}$ & $\begin{array}{l}\begin{array}{l}\text { Loi sur } \\
\text { publiques. }\end{array} \\
\text { pus écoles }\end{array}$ \\
\hline & 2004 & $\begin{array}{l}\text { À l'appui des écoles } \\
\text { favorisant l'inclusion : } \\
\text { Planification scolaire et } \\
\text { communication des } \\
\text { renseignements : un } \\
\text { cadre pour l'élaboration } \\
\text { et la mise en œuvre des } \\
\text { plans scolaires et des } \\
\text { rapports annuels. }\end{array}$ \\
\hline $\begin{array}{l}\text { Newfoundland and } \\
\text { Labrador }\end{array}$ & $\begin{array}{l}1997- \\
2016\end{array}$ & School act \\
\hline \multirow[t]{2}{*}{$\begin{array}{l}\text { Northwest } \\
\text { Territories } \\
\end{array}$} & 2006 & $\begin{array}{l}\text { Ministerial Directive on } \\
\text { Inclusive Schooling }\end{array}$ \\
\hline & $\begin{array}{l}1995- \\
2016\end{array}$ & Loi sur l'éducation \\
\hline \multirow[t]{2}{*}{ Nova Scotia } & 2008 & Special Education Policy \\
\hline & $\begin{array}{l}1995- \\
2015\end{array}$ & Education Act. \\
\hline \multirow[t]{2}{*}{ Nunavut } & 2008 & $\begin{array}{l}\text { Foundation for Inclusive } \\
\text { Education Inuglugijaittuq } \\
\text { in Nunavut Schools }\end{array}$ \\
\hline & 2008 & $\begin{array}{l}\text { Education Act: A } \\
\text { reference guide for the } \\
\text { commission scolaire } \\
\text { francophone and school }\end{array}$ \\
\hline
\end{tabular}




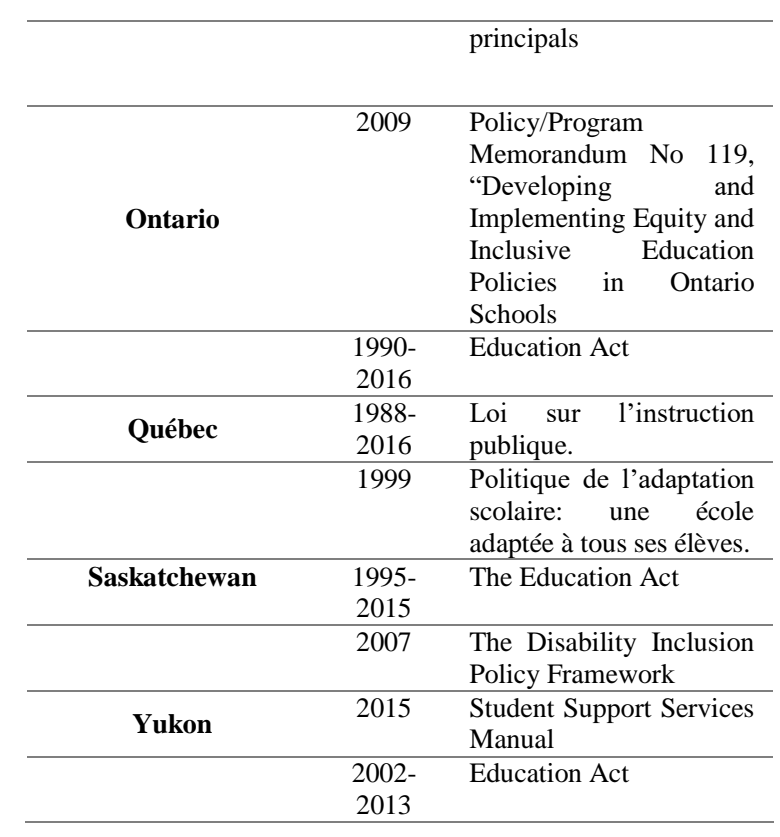

Intervention models for special needs students of the 13 Canadian education jurisdictions were thus examined and compared with regard to their respective components, stages of elaboration, and functions. The terminology used to designate the intervention model, its required elements, and its development stages constituted the formal analysis of the IP, while the functional analysis centered on the seven identified functions of the IP (communication, identification, planning, collaboration, adaptation, review, and transition).

\section{Results}

The ten provinces and three territories of Canada share no universal definition of an individualized education plan, despite similar interpretations. For example, the province of Manitoba [17] describes the IEP as a written document, created and implemented by a team, which presents a plan designed to meet the unique learning needs of a student. Several other provinces and territories corroborate this interpretation [18] [19]. To this definition, the Northwest Territories [20] add a consideration for the student's specific needs by referring to a global written plan that documents the student's annual outcomes that are determined through a process of collaboration that is guided by the student's strengths, needs, and interests. Indeed, the idea that the IEP necessarily involves a collaborative process led by a team of educators was found to be a common thread among most of the provinces and territories, except for British Columbia [21] whose general definition of the special needs individualized education plan regards a document drawn up to summarize and document a special needs student's individual learning program.

\subsection{Formal analysis}

The presence of the term "individualized education plan" is rare in official provincial and territorial documentation. Indeed, only three provinces and two territories briefly mention the individualized education plan and its usage in their respective education acts: Québec, British Columbia, and the Northwest Territories [22] [23] [24]. Despite its legal status, the IEP appears only in Type III documentation across the country in the form of instruction manuals, and although the province of Saskatchewan [25] has a policy (Type II) with regard to IEPs, it is the only one who does not have any guide on the subject.

5.1.1. Terminology. The review of the different official documents published by the ten provinces and three territories uncovers a variety of terms to designate the instructional method called the individualized education plan. The official English appellation "Individualized Education Plan" or IEP is the term most often used in the majority of Canadian jurisdictions (six provinces and two territories), while Prince Edward Island and Manitoba authorize the use of another variant, namely "Individualized Education Planning". The second most frequently used term, the "Individual Program Plan", is employed in the provinces of Alberta and Nova Scotia. Finally, three provinces have their own distinct definitions to designate this individualized support action: Saskatchewan, Nunavut, and New Brunswick. Moreover, there appears to be a general tendency to use the term "individual" or its derivatives in reference to one characteristic of the individualized education plan, which is meeting the specific needs of the student for whom this instructional tool has been designed; indeed, 11 of the 13 provinces and territories use this particular term to designate the individualized education plan, while New Brunswick uses "personalized" and Saskatchewan uses "personal".

5.1.2. Components. To help the intervention team to create a tailored plan adapted to a student's specific needs, each province and territory (except for Nunavut) has an established intervention template containing the appropriate required components. Across the country (except for the Yukon), despite the obligation of schools to provide individualized education plans for their special needs students, there is evidence of a certain flexibility in terms of how the plan is presented, with greater focus on content. In Alberta [26], for example, the individualized education plan must be used in a selective manner and may be adapted to better address the needs of each student, while in Manitoba [17], its presentation, length, details, and exhaustivity must correspond to the student's needs. 
The use of the intervention template in these provinces and territories comes across as more of a recommendation than an official request. In the Yukon [27], however, the intervention team appear to be required to fill in certain pages of the proposed intervention template, such as student profile and anticipated goals and objectives. Aside from personal information (age, file data, signatures, etc.), the individualized education plan usually consists of the following elements: a summary exposing the student's strengths, difficulties and challenges, assessments from specialists or the teacher, the anticipated objectives of the implemented plan, the resources available for the student, the envisioned methods and strategies to reach the established goals, a description of the roles of each contributing member, a review and evaluation of the plan, any anticipated adaptations or changes, and finally, the presence or absence of a transition proposal, if applicable.

The assessment of the student's strengths corresponds to a description of their current overall skills, abilities, assets, and positive learning outcomes. Also documented are the student's weaknesses, specific needs, and the challenges identified following an assessment which the student is required to succeed during the school year. The component pertaining to the objectives refers to the goals pursued by the developed individualized education plan, such as targeted skills, responsibilities, capabilities, or abilities. To reach the established objectives, any planning requiring specific teaching techniques and strategies is then introduced. Generally speaking, IEPs also house a section covering the resources made available for the student to provide the necessary support and guidance to reach the anticipated outcomes. This may include human and financial resources. Alberta goes further by insisting that one section of the plan be reserved for review recommendations and its general components to ensure that they are always up to date [26]. As for adaptations and modifications, the former represents measures that do not alter the initial objectives associated with the corresponding education program for a given grade, while the latter amends these objectives. Finally, most of the individualized education plan templates proposed by the provinces contain a section that enables to demonstrate the transition between the current academic status of the student and the previous one.

Among the 13 education jurisdictions in Canada, Nunavut is the only one who does not have an IEP template. As for the other provinces and territories, only three of them (Alberta [26], British Columbia [21] and Saskatchewan [25]) propose a model in which all of the components are present. In contrast, the province of Nova Scotia's canvas appears to contain the lowest number of components, thus excluding the sections on the student's strengths/weaknesses, the methods/strategies proposed to reach the objectives defined in the individualized education plan, the available resources, the adaptations/modifications with regard to instruction and assessment, and the transitional measures. What their template does contain, however, similar to some other jurisdictions, is a full page devoted to relevant comments which may be inserted in the report, thereby adding flexibility to its content.

Regarding each of the different components, they appear to be generally presented in almost all of the templates proposed by the Canadian provinces and territories. For example, the template models of the Northwest Territories [20] and Newfoundland and Labrador [28] do not include sections on the general objectives to be pursued, as the necessary adaptations and support measures to address the needs of the student are the focus. Of interest, however, is that close to half of the jurisdictions in the country do not set aside a specific section in their IEP to facilitate the transition of a special needs student from one year to the next. Also noteworthy is that in Manitoba [17], there is no direct reference to the general objectives of the intervention; instead, the template employs terms such as "learning outcomes" and "performance objectives" to indicate this component.

On another note, the IEP template proposed in Ontario appears to suggest a difference between instructional, environmental, and evaluatory adaptations and those envisioned during the provincial assessment. Finally, in Québec [29], the techniques/strategies to attain the objectives of the IEP and the adaptations/modifications to enhance the student's performance are viewed as complementary and are grouped together in the same section.

5.1.3 Stages. As mentioned, according to the MEQ [13], an individualized education plan consists of a dynamic process of strategically planned support for the student and thus involves a series of coordinated actions. Overall, in Canada, the IEP appears to emanate from three main actions, namely, identification/data collection, implementation, and finally, review/evaluation. As indicated by Alberta [26], the first action is identifying the strengths of the student and their specific learning needs. The current situation of the student having been determined, the team of specialists decides which strategies and adaptations to use to reach the desired pedagogical objectives. This stage corresponds to the drawing up of the IEP, which is a sub-category of the implementation. It is also in this period of the process that data is recorded in the IEP [13]. The second sub-category of the implementation stage of the process is the deployment of the actual interventions. The final stage of the process consists in evaluating the data gathered in the intervention 
report (annual goals, learning expectations, teaching strategies, as well as all of the external resources involved [16]. If necessary, the changes introduced are added to the individualized education plan. There is a general tendency in Canada to view identification and data collection as the first stage of development of the IEP. That said, Alberta, Ontario, Saskatchewan, and the Northwest Territories add a step which may also be performed at this point: choosing the direction.

For Alberta [19], establishing the direction of an IEP implies that the intervention team determine priorities based on the data collected from the student. As for Saskatchewan and the Northwest Territories, these jurisdictions suggest that establishing the direction of the IEP should come first, while Alberta and Ontario propose this action following the one involving identification/data collection.

For the sake of analysis, grouping together the stages of elaboration and implementation within the more general category of "implementation" is relevant, considering that the province of Newfoundland and Labrador and the territory of Nunavut do not directly mention the development of an IEP in their respective reference frameworks. And yet, considering the nature of the IEP, its usual functions [13], and objectives, it is part of a process that naturally warrants an outcome. There is thus reason to think that some jurisdictions have no formal distinction between the stages of elaboration and implementation of the IEP, as both actions can be included within the other appelation. However, Prince Edward Island is the only province whose review/evaluation section of the IEP is not part of its reference framework and may thus be considered as optional, as it has no bearing on the completion of the report. The IEP process in Alberta adds an additional stage which does not appear in the table, namely, that of ensuring the transition of the instructional interventions from one school to another.

\subsection{Functional analysis}

The functional analysis centers on the seven identified functions of the IEP (communication, identification, planning, collaboration, adaptation, review, and transition).

5.2.1. Communication. Because this function is found in each stage of the process of the IEP, it is analyzed as a metafunction. By its very nature, the IEP systematically exploits the function of communication, and this is observed throughout Canada. Indeed, the 13 jurisdictions appear to concur that continuous communication between the different members of the intervention team is crucial to the success of the strategies and interventions chosen for the special needs student [16] [21].

5.2.2. Identification. In Canada, two methods are used to determine whether a student has special needs. The first requires a definitive medical diagnosis attributed to the student, which leads directly to the development of an IEP. The second corresponds to screening and results in an assessement of the student's situation by a committee who determines that the student's difficulties call for interventions personalized for them. More than half of the country ( 8 out of 13 jurisdictions) employ these two approaches prior to developing an individualized education plan [16] [21] [18]. Newfoundland and Labrador [30] is the only province to refer only to the medical diagnosis, while four other provinces prefer a non-categorical approach by screening the student's needs [31]; [32].

5.2.3 Planning. As part of the cyclical process of elaboration of an IEP, the function of planning begins as soon as a student is identified as having special needs that call for specific actions. Here, planning means identifying which actions are to be taken to support achievement for this student [31]. To respond the most effectively to the student's situation, the intervention team focus their actions on the same goal while determining the responsibilities of each member; there are, however, variations between provinces and territories in regards to these roles. Indeed, across Canada, the school principal generally serves as official leader of the individualized education plan (11 of 13 jurisdictions). On the other hand, the role of the parents in this process varies considerably, as 7 out of 13 jurisdictions state their presence [26] [31] as being "necessary", while the others merely recommend that the parents participate.

5.2.4. Collaboration. This function is basically observed in pedagogical action once the planning around the student's needs and the relevant objectives have been determined. Across the country, the collaborative approach is the method of choice, with a few variations. For example, in British Columbia [21], further to its perspective of problem solving, the collaborative process emphasizes open communication between the members of the intervention team, similar to what goes on in the province of Québec [13]. Moveover, in three jurisdictions, seeking advice and knowledge from experts is viewed as an integral part of the collaborative process.

5.2.5. Adaptation. This function corresponds to the different accommodations (adaptations and modifications) chosen and authorized for the special needs student within the framework of the 
individualized education plan. With the exception of Nova Scotia [32] and Newfoundland and Labrador [30], there is a inclination to include these personalized adjustments and modifications directly in the individualized education plan. Only Nova Scotia separates the two by placing adjustments in the student's file and modifications in the individualized education plan.

Of interest is that the 13 Canadian jurisdictions have established an extensive list of accommodations for these students (depending on the difficulty) during their provincial assessments, including general adaptations pertaining to the presentation of the assessments and increased time allotments to complete these exams. Here, the Northwest Territories [33] are the exception by not considering CITs among its official accommodation measures.

5.2.6. Review. As shown in Figure 1, the review takes place at the end of the process and helps to determine the relevance of pursuing the individualized education plan as it was conceived for the special needs student. While most Canadian jurisdictions recognize the importance of this element, there are nuances in terms of the recommended frequency of review. Indeed, the government of Nunavut [34] indicates no such recommendation as to how often the IEP should be revised, while the other jurisdictions include this directive, which varies considerably depending on location. Four jurisdictions recommend an annual review, at the end of each school year [17] [21]. In the provinces of Québec and New Brunswick, there is no definite schedule of review; as each IEP is different and the situation varies depending on the needs addressed [13] [31].

5.2.7. Transition. The intervenion plan ensures the function of transition when it allows for of continuity instructional measures to ease the passage from one environment to another [13] [17] [18]. By taking advantage of what worked with the student up to now, the function of transition becomes relevant, particularly at the end of a cyclical process. Some Canadian provinces and territories have welcomed transition as an integral part of the IEP, while others prefer a separate document.

\section{Conclusion}

The individualized education plan is now a shared and supported method with several commonalities. Yet while the IEP is used daily in today's schools and its implementation issues have been resolved, its legal premises continue to vary significantly from one education system to another. The same can be said regarding the quantity and quality of documents defining its use in Canada's different provinces and territories. Overall, however, these intervention plans contain similar elements and implementation processes, meaning that although they may differ, their ultimate goal is the same.

The functions are also basically the same across the country, except regarding the function of identification. Indeed, this relatively new function differs significantly among the provinces and territories, through such transformations as inclusion and the non-categorical approach. Focusing on the nature rather than the causes of the student's difficulties holds the school team accountable for the function of identification. That said, there is evidence of a transition in Canada, particularly in categorical provinces. In British Columbia, for example, both a diagnosis and 30 hours of intervention with a remedial teacher may serve for this identification. Provinces using a non-categorical system have included this new function in their IEP, while categorical provinces such as Alberta and Ontario are now open to allowing the use of IEPs without the need for a diagnosis. Moreover, while each function is presented linearly within the cyclical configuration of the IEP (see Figure 1), results indicate that aspects of some of them manifest over a wider time period, such as the function of collaboration which has been mainly studied under the angle of its occurrence after the meeting to establish the IEP, even if it may also take place beforehand.

The fact that certain functions not explicitly expressed in the existing documentation does not mean that these stages of action are not part of the IEP of a particular province or territory or team responsible for its implementation.

\section{References}

[1] S. Higgins and J. Barresi, "The changing forces of public policy”, Exceptional Children, 45(4), 1979, pp. 270277.

[2] D. Poirier, L. Goguen, and P. Leslie, Education rights of exceptional children: A national study of multi-level commitment, Carswell, Vancouver, 1988.

[3] A. Aucoin, L. Goguen, and R. Vienneau, "Pas plus spécial que nécessaire: analyse des politiques scolaires de la Nouvelle-Écosse à l'égard de l'inclusion scolaire des élèves avec handicaps", Education et Francophonie, 39(2), 2011, pp. 23-49. http://www.acelf.ca/c/revue/pdf/EF-39-2023_AUCOIN.pdf. (Acces date 28 March 2016).

[4] K. Rotter, IEP used by general and special education teachers. SAGE Open. April-Jun, 1-8. Plan (IEP) goals and objectives, Journal of Early Intervention, 23(2), 2014, pp. 92-105.

[5] D. Mitchell, M. Morton, and G. Hornby, Review of the literature on Individual Education Plans: Report to the New Zealand Ministry of Education, Christchurch, New Zealand, 2010. 
[6] E. Drasgow, L. Mitchell, and T. Rowand Robinson, Developing Legally Correct and Educationally Appropriate IEPs. Remedial and Special education, 22(6), 2011, pp.359-373.

[7] S. Rodger, Individual education plan revisited: A review of the literature. International Journal of Development and Education, 42, 1995, pp.221-239.

[8] C. Christle and M. Yell, Individualized Education Programs: Legal Requirements and Research Findings, Exceptionality, 18(3), 2010, pp. 109-123.

[9] S. W. Smith, Individualized education programs (IEPs) in special education: From intent to acquiescence. Exceptional Children, 57, 1990, pp. 6-14.

[10] Gouvernement du Canada, Loi constitutionnelle de 1867, Canada Retrieved from http://laws-lois.justice.gc.ca /fra/const/page-1.html (Access date 28: March 2016).

[11] R. Legendre, Dictionnaire actuel de l'éducation (3rd ed), Guérin, Montréal, 2005.

[12] E. Barton, "Individual education plan", Encyclopedia of Autism Spectrum Disorder, Springer, New Haven, CT, 2013, pp. 1569-1574.

[13] Québec, Le plan d'intervention... au service de l'élève : cadre de référence pour l'établissement des plans d'intervention, Ministère de l'éducation, Québec, QC, 2004. Retrieved from http://www.mels.gouv.qc.ca /fileadmin/site_web/documents/dpse/adaptation_serv_com pl/19-7053.pdf7. (Access date: 28 March, 2016).

[14] D. Bateman and C.F. Bateman, A Principal's Guide to Special Education, Council for Exceptional Children, Arlington, VA, 2001.

[15] South Dakota Department of Education, Individual Education Program (IEP): A Technical Assistance Guide, Special Education Programs, Pierre, SD, 2013.

[16] Ontario, Plan d'enseignement individualisé (PEI), Ministère de l'Éducation, Toronto, ON, 2004.

[17] Manitoba, Plan éducatif personnalisé: guide d'élaboration et de mise en œuvre d'un PEP, Éducation Manitoba, Winnipeg, MB, 2010.

[18] Prince Edward Island, Individualized Educational Planning (IEP): Standards and guidelines, Department of Education, Charlottetown, PEI, 2005.

[19] Alberta, Individualized Program Plans, Ministère de l'Éducation, Edmonton, $\mathrm{AB}, 2005$. Retrieved from http://www.learnalberta.ca/content/kes/pdf/or_ws_tea_ld_b _01_ipp.pdf. (Access date: 28 March, 2016).

[20] Northwest Territoires, Northwest Territories Individual Education Plans: Guidelines for Development and Teacher Resource Kit, Education Culture and Employment, Yellowknife, NT, 2006.
[21] British Columbia, Individual Education Planning for Students with Special Needs: A Resource Guide for Teachers, Ministry of Education, Victoria, BC, 2009.

[22] Québec, Loi sur l'instruction publique, Chap. I-13.3, Ministère de l'Éducation, Québec, QC, 1988. Retrieved from http://www2.publicationsduquebec.gouv.qc.ca/ dynamicSearch/telecharge.php?type=2\&file=/I_13_3/I13 3.html. (Access date: 28 March, 2016).

[23] British Columbia, School Act, Ministry of Education, Victoria, BC, 1996.

[24] Northwest Territoires, Loi sur l'éducation, Ministère de l'Éducation, Yellowknife, NT, 1995. Retrieved from https://www.justice.gov.nt.ca/fr/fichiers/legislation/educati on/education.a.pdf. (Acces date 28 March 2016).

[25] Saskatchewan, Policy, Guidelines, and Procedures for Functional Integrated Program, Saskatchewan Learning, Régina, SK, 2006.

[26] Alberta, Pour démarrer: travailler le processus d'élaboration du PIP, Alberta Education, Edmonton, AB, 2007.

[27] Yukon, Special Program Services: A Handbook of Procedures and Guidelines, Department of Education, Whitehorse, Yukon, 1995.

[28] Newfoundland and Labrador, Individual Education Plan (IEP) Summary, Department of Education, St-John's, NL, 2012a.

[29] Québec, Plan d'intervention. Ministère de l'Éducation, du Loisir et du Sport, Québec, QC, 2012.

[30] Newfoundland and Labrador, Service Delivery Model for Students with Exceptionalities Forms. Department of Education and Early Childhood Development, St-John's, NL, 2011.

[31] Nouveau-Brunswick, Le plan stratégique et l'équipe stratégique: soutenir les élèves à besoins particuliers dans leurs apprentissages, Ministère de l'Éducation, Services aux élèves, Moncton, NB, 2010.

[32] Nouvelle-Écosse, Politique en matière d'éducation spéciale, Ministère de l'Éducation, Services aux élèves, Halifax, NE, 2008.

[33] Northwest Territoires, The NWT School Handbook 2012-2013, Education Culture and Employment, Yellowknife, NT, 2013.

[34] Nunavut, Foundation for inclusive education in Nunavut schools, Curriculum and School Services Division, NU, 2008. 